\title{
Healthy from the Village \\ (Village Communities Health Empowerment Strategy Based on Capacity Development)
}

\author{
Saputra Adiwijaya ${ }^{1}$ \\ ${ }^{1}$ Department of Sociology - Faculty of Social and Political Sciences - University of \\ Palangkaraya - Central Kalimantan \\ E-mail: s_adiwijaya@ymail.com
}

\begin{abstract}
The village as the smallest government in the formal scope of the unitary state of the Republic of Indonesia is currently an interesting focus to study, especially since the Village Fund Allocation (ADD) was rolled out by the central government of 1 billion per village, making the village actively build in all aspects. One of the focus in the development of the village communities is the health sector, as this area is considered as one of the main pillars in the effort to build a nation.

Empowerment in the health sector is absolutely necessary as an alternative in adjusting the varying conditions of villages in Indonesia, in other parts the empowerment program also refers to adjustments from the world programs contained in the SDG's (Sustainable Development Goals).

This paper tries to give perspective about the urgency of health empowerment for village communities based on capacity building as one of the ideas offered in preparing technical policies for the health sector in the village.

In another section details the empowerment program for village communities which are based on the capacity development aims to facilitate the passage of the program and must be adjusted to the potential of the existing village.
\end{abstract}

Keywords : Village, Empowerment, Village Communities Health, Capacity

Development

\section{Preliminary}

Concerns about community empowerment, especially for rural communities, are now undergoing a lot of change, this is also supported by the direction of the development program in Indonesia has been so dynamic. Various studies and research provide results which certainly contribute to the development of the village as the last basis to provide a new understanding of the meaning of the village that remains beautiful but modern, including independence. Or also maintain local wisdom but still be able to adjust the whole village without being eroded by globalization.

Including the community as part of development policy has become a major issue in recent years, bottom-up policies in accordance with the needs of the community make the 
government align with various programs so that the results of the development process are on target. But in other parts there are still many shortcomings, the village is still seen as an area that is left behind in everything. Whether it's the infrastructure, human resources, until the issues are rife current financial abuse is occurring village by headman would lead to renewed conflict resulted in the villages. There is a new problem that precisely since the village funds were rolled out rather than to achieve the targets of village development programs, in fact in some cases the headman has misused village funds, or used village funds for personal gain.

One important issue for village development is the health sector recorded many health programs is a priority, such as the availability of clean water, improvement Polindes, reactivation of Posyandu, to be provided salaries for health workers in the villages. This actually cannot be separated from the ideal ideal that health is actually one of the basic needs for every human being.

Since the village fund was rolled out, it was noted that the results of infrastructure development to fulfill basic health needs included clean water infrastructure 42,209 units, wells 6,334 units, MCK 22,049 units, drainage 32,788 units, posyandu 20.303 units, polindes 2,568 units, sports facilities 12,794 villages. (Technical guidelines for village article writing, 2018).

From these data have a lot of improvement in the quantity of which is already built, but which could later be questioned what all then once built can run effectively all of the programs, how to villages in the hinterland, and much more real can lead to long discussions.

\section{Number of villages in Indonesia}

Determining the direction of health development when viewed from the eyes of the village for Indonesia in the category of countries comprises many islands that many would require an appropriate strategy, this can be based on a simple problem, for example on one side of the territory in Indonesia can be seen progress but in some other parts still very far behind, especially in the countryside. This situation is also reduced if the villages in the island of Java are certainly more advanced than villages outside Java.

According to data from the Central Statistics Agency (BPS) and the Ministry of Home Affairs (Kemendagri) the number of villages in Indonesia is increasing, there is a unification of hamlets as a condition of the formation of villages that are increasingly growing. Based on data compiled from BPS the number of villages in 2003 the number of villages was 4749 villages, then in 2014 there were 62517 villages (bps.go.id). Meanwhile in 2016 in accordance with the exposure of the Directorate General of Budget (DJA) Ministry of Finance, Village Fund Accountability, which refers to data from the Ministry of Home Affairs, said the number of villages previously in 2015 totaled 74,093, an increase of 661 villages, and now in the year 2016 the number of villages in Indonesia reached 74,754 villages.

The increasing number of villages from year to year can actually be seen by that it set in the village expansion mechanism pursuant to Act 6 of 2014 on the village, the village expansion requirements include:

1. Limit of the age of the main Village at least 5 (five) years from the establishment;

2. The number of inhabitants, (must be in accordance with the amount set out in Article 8 of the Act 6 concerning Villages);

3. Work areas that have access to transportation between regions;

4. Socio-culture that can create harmony in community life in accordance with village customs;

5. Has potential that includes natural resources, human resources, and supporting economic resources;

6. Village boundaries stated in the form of Village Maps as stipulated in the Regents / Mayors regulations;

7. Facilities and infrastructure for the Village Government and public services; and 
8. Availability of operational funds, fixed income and other benefits for the apparatus of the Village Government in accordance with the provisions of the legislation.

So that based on the above regulations, the number of villages will increase in number because it will simply allow the number of villages to develop (guaranteed by existing regulations). In another part of the increasing number of villages should be able to improve the welfare of the villagers it also can accelerate development, including in it certainly is the health sector for the villagers.

\section{Concept of Village Health Empowerment Model}

Understanding the direction of health policy for the village, of course, that must understand it is fundamental that the purpose of the health sector program should be addressed to the villager communities (human), because human resources are the focus of the development of a country. As a conceptual guideline using the Human Development Index (HDI) is a comparison measurement that starts from:
a. Life expectancy
b. Literacy and education
c. Standard of living

The HDI is used to classify whether a country is a developed country, developing country or underdeveloped country and also to measure the influence of economic policy on quality of life, then also in the Human Development Index (HDI) is one way to measure the level of physical and non-physical quality of the population. Physical quality is reflected in life expectancy; while non-physical quality (intellectuality) through the length of the average school population and literacy rate; and consider the economic capacity of the community as reflected in the value of purcashing power parity index (PPP).

By the Indonesian government this HDI was then sent down to each province, and then the value could be found nationally so that the final value of each of these provinces became Indonesia's HDI. For each province the HDI value may be different, although accompanied by general indicators that have been compiled. The main objective of the measurement of the HDI is to create a good quality of life so that it can improve the basic capacity of the community in sustainable development.

Then in addition, of course there are goals from the MDG's (Millennium Development Goals) which are then followed by SDG's (Sustainable Development Goals) because Indonesia as a part of the world inevitably has to comply with UN goals, and specifically for Indonesia the latest health policy the existence of the BPJS (Social Security Administering Body) in which it relates to citizens' health care.

Empowerment is interpreted simply as an alternative to development that includes the community to play an active role in development programs, in the process ideas that come from the community become guidelines for developing policies. If the government previously provided a top-down program, then in the context of empowerment, the community is given the space to adjust their situation and their environment according to their needs (bottom-up). There is a space for sharing power in this government to the public, this is then the opportunity for the community to be able to determine their own destiny according to their needs by remaining guided by the development policies or programs that are the direction of the government. The concept of village empowerment in Indonesia with all kinds of regional potential, human resources, and customs, of course requires different models of empowerment, this is the challenge for the government, as well as for the whole community. The concept of health empowerment if understood will find a final concept, namely the independence of the community in the health sector. 
Community empowerment of health efforts so that Indonesian people become healthy is in accordance with the Act of the Republic of Indonesia Number 36 of 2009 concerning health, that health development must be aimed at increasing the highest awareness, willingness and ability of community life, as an investment for the development of community resources. Everybody is obliged to participate in realizing, maintaining and improving the community's health status as high as possible. The government is responsible for empowering and encouraging the active participation of the community in all forms of health efforts.

The empowerment strategy for the village focuses primarily on households, then on community groups, using village funds. as is known the village gets funds disbursed from the APBN on average Rp. 1 billion per village every year. This amount of funding will be very significant for the empowerment of village communities. Clean and Healthy Life Behavior (PHBS) and the development of Community-based Health Efforts (UKBM) will be more likely to be pursued at the household level in the village. There is a paradigm shift emphasized in village communities that the healthy paradigm is an effort to keep healthy people healthy, suppressing promotive and preventive services. These two things are mutually supportive and can work together, because this is where the scope of health is in the community. A simple example is the suggestion that hand washing before eating is a preventive measure, then raising awareness to breastfeed a baby with breast milk is an example of promotive action. Both of these if done according to the conditions of villages in Indonesia are very possible, because health programs for villagers will be easily achieved.

\section{Current Village Conditions}

In maximizing health empowerment in the village coupled with the use of village budget funds, The Ministry of Health has made a pocket book as a guide in the allocation of village funds with the aim of its activities, namely the improvement of the implementation of health empowerment and promotion to the community and the indicators of achieving these targets, among others, the percentage of villages that use $10 \%$ village funds for UKBM by $50 \%$.

Then when viewed from the existing problems according to the Central Statistics Agency (BPS) in 2014 that all villages in Indonesia experienced pollution, there were three pollution that became reference to this data, namely water pollution, soil pollution and air pollution. From each of the three indicators, it can be seen that actually village problems in Indonesia are vulnerable to pollution.

From the data, villages in Java are very vulnerable to pollution, for example villages in West Java Province, which have been polluted by 1,131 villages, to contaminate village land in Central Java Province, 183 villages, but for the village category with air pollution. in fact there are 2,076 villages in North Sumatra Province. Besides that, it can also be seen that the number of villages that experienced the least water pollution was West Sulawesi Province as many as 22 villages, then for the least amount of village land pollution in DKI Jakarta Province as many as 2 villages, while for the villages that experienced the least air pollution were in DKI Jakarta Province is 17 villages.

This data was indeed 4 years ago, but what critics say about the current conditions (the latest data), with DKI Jakarta Province being the village with the least pollution, is it, or assuming that the behavior of the villagers in DKI Jakarta is such healthy so that the least experienced pollution, or also when compared to that of the villagers outside Jakarta is underdeveloped in health consciousness so high pollution level.

If the prism of the data above, the main challenge is that the villages too which have been considered as a comfortable, beautiful and beautifully turned out to save the vulnerability to pollution, who is then responsible turns the focus of preventive and promotive, in some cases, be curative and rehabilitative especially for villagers. 


\section{Health Capacity Development in the Village}

What can then be used as a model solution to health problems in the village when all villages in Indonesia are polluted, while in other parts of poverty is also an important thing to be explained. Different villages are certainly different from the empowerment model, villages in the interior, villages on the coast, villages in the valley, and all the characters that require a plan and action that cannot be of origin. A concept given by the United Nations International Children's Emergency Funds (1999), that empowerment is defined as a process of enabling people to increase control over decisions and actions that affect public health, aims to mobilize vulnerable individuals and groups by strengthening basic life skills and increasing influence on matters that underlie social and economic conditions. Then also in another section it is stated that community empowerment is all facilities that are non-instructive facilities to improve the knowledge and ability of the community to be able to identify problems, plan, and solve them by utilizing local potential and existing facilities, both from cross-sectoral institutions and NGOs and community leaders.

There is a synergistic collaboration of all parties, that pollution in the village can be said to need serious attention. In other parts of the local government, for the sake of PAD (Regional Original Revenue), it also contributes to the role of pollution, for example, it is easy to give mining permits, average plantation permits without proper study, thus contributing to all this. There are things that influence each other on the one hand the local government needs to charge for development for the benefit of the villagers, but on the other hand nature and the environment are sacrificed, the most affected by this is certainly the village community.

Capacity building or in some concepts equated with capacity strengthening can be an alternative to gradually improve this. According to UNDP (United Nations Development Program) and CIDA (Canadian International Development Agency) in Milen (2004) provides an understanding of capacity building as a process by which individuals, groups, organizations, institutions, and communities improve their ability to:

a. Produce performance implementation of core tasks and functions, solve problems, formulate and realize the achievement of the stated goals.

b. Understanding and meeting the needs of development in a broader context in a sustainable way.

This is in line with the concept of capacity development according to Grindle (1997) which states that capacity building as an ability to perform appropriate task is effective, efficient and sustainable. This is interpreted as an ability to perform tasks that are effective, efficient and sustainable. then Strengthening capacity by Eade and William in Shaughnessy (1999), is: "... Strengthening people's capacity to Determine Reviews their own values and priorities and to organize Themselves to act on Reviews These, the which is the basic for development." It is understood that "... strengthen the capacity of people to determine their values and priorities and to organize themselves and act in activities that are the basis of development".

Furthermore, from the same source it was also stated that there were three elements as capacity strengthening, namely:

1. Human development is mainly in the fields of health, education, food, technical skills.

2. Restructuring government and private organizations to create skilled workers can function effectively socially.

3. The political leadership that understands that the institution is a unity that is fragile and easily destroyed, therefore, requires the development of a sustainable activity. 
In connection with the three elements of capacity building mentioned above, it is necessary to strengthen the capability of personal characteristics as the management of the organization in terms of health, in the form of education and technical skills and financial support for organizational progress. Then organizational restructuring can be useful in personal placement according to expertise (the right man on the right place) in order to function in organizational activities such as enthusiasm and ability to cooperate will improve the quality achieved continuously.

Another opinion is also said that what is meant by capacity building is to describe a series of actions ranging from developing human capacity / capabilities directly, restructuring the organization and marketing of labor. Capacity strengthening is a change in the behavior of individuals, organizations and community systems in achieving goals that are effectively and efficiently.

Therefore according to Supeno (2002), capacity strengthening means behavior changes to:

1. Improve individual abilities in knowledge, skills and attitudes.

2. Improve institutional capacity in organization and management, finance and culture.

3. Improve the ability of the community in independence, self-sufficiency and anticipating change.

It can be done is simple especially in the rural sphere, for example:

1. Socializing knowledge and insights to citizens about the diseases that will arise due to pollution, impacts and prevention as to what and how, this can be done by coordinating with the health department.

2. Train health cadres (in groups) to identify what diseases people often suffer from pollution, while still coordinating with the health department.

3. Reporting to the authorities can go to village officials, health services, or if possible to the police if there are findings of pollution in rural areas

4. Make lots of pilot areas in the village for pollution prevention.

5. Always maintain nature and the environment around rural areas.

6. Conduct a time-adjusted evaluation according to the priority program or activity.

There is readiness and strategy so that all of this can work well, coordination to synergize between the government, village officials, and villagers. Because in the context of the discussion of capacity building that individuals must be skilled as health cadres, then form health cadre groups, then supported by the government. There is room for the villagers to determine which is best for them in accordance with the positive issues that exist in their environment, with regard to the potential which is owned by the village, and also perhaps whether there is a conflict when all the issues - the positive issues applied.

There is a high expectation that the priority of the use of village fund allocation can run well and maximally, especially for the health sector, especially in the village. Required middle way to really pay attention to the best decisions for the village, so the village could avoid misappropriation of funds. On the other hand physical development is also important, for example roads, bridges, all of which are inseparable parts of the constructing village because so far the access of the citizens is hampered due to the lack of facilities.

\section{Conclusion}

In the coming years, villages in Indonesia will always increase, and of course this will increase the burden on state expenditures, there must be appropriate priorities from each village to determine its development, accompanied by an adequate evaluation. The health sector for the villagers must be a thing that also gets attention, because villages that are considered as beautiful, comfortable, or beautiful areas are vulnerable to pollution. 
There will be many models of empowerment, especially for the health sector because each village in Indonesia has a different character, so the support of the government as having more power must move all the potential that exists in the village, such as human resources, village areas, superior products and so forth for the realization an independent village. One model that can be used is by developing capacity in supporting development programs for villages.

\section{References}

Grindle, M.S., (editor).1997. Getting Good Government : Capacity Building in the Public Sector of Developing Countries, MA: Harvard Institute for International Development. Boston.

Milen,Anni. 2004. Pegangan Dasar Pengembangan Kapasitas. Diterjemahkan secara bebas. Pondok Pustaka Jogja, Yogyakarta.

Paparan Direktorat Jenderal Anggaran (DJA) Kemenkeu, Akuntabilitas Dana Desa, Berdasarkan Kementerian Dalam Negeri per tanggal 29 Juni 2016.

Shaughnessy With Leanne Black and Helen Carter. 1999. Capacity Building A new approach Principles And Practice, Australia.

Supeno. 2002, Capacity Building, Persiapan dan Perencanaan , Catholic Relief Services, Jakarta.

United Nations Children's Fund, Programme Cooperation for Children and Woman from a Human Rights Perspective Internal Document), UNICEF Executive Board paper E/ICEF/1999/11, New York, April 1999.

Undang - Undang Republik Indonesia Nomor 36 tahun 2009 tentang Kesehatan

Undang-Undang Republik Indonesia No.6 Tahun 2014 tentang Desa

\section{Source from the Internet:}

https://kemendesa.go.id/view/detil/2295/lomba-menulis-artikel-dana-desa. accessed March 7, 2018, at 11.03 WIB.

https://www.bps.go.id/statictable/2015/02/09/1763/banyaknya-desa-kelurahan-menurut-jenispencemaran-lingkungan-hidup-2014-.html accessed March 7, 2018, at 06.50 WIB.

https://www.bps.go.id/linkTableDinamis/view/id/907 accessed March 7, 2018, at 08.20 WIB. https://www.kemenkeu.go.id/media/6750/buku-saku-dana-desa.pdf accessed March 6, 2018, at $06.50 \mathrm{WIB}$.

ipm.bps.go.id/assets/files/ipm_2006_2007.pdf accessed March 6, 2018, at 23.20 WIB. 